\title{
Emotional Intelligence and Academic Achievement of University Students
}

\author{
Mushtaq Ahmad* \\ Asghar Ali** \\ Bakhtawar Tariq $^{* *}$
}

\begin{abstract}
This research was conducted to explore the emotional intelligence of university students and its relationship with their academic achievement. Through multi stage random sampling technique sample of 400 students of undergraduate (BS) final semester was selected including 160 males and 240 females 14 departments out of 7 faculties of university of Sargodha main campus. Baron Emotional Quotient Inventory (Short form) was adapted as a research instrument, validated through expert's opinions and pilot testing with reliability coefficient Cronbach Alpha values 0.86 . Data were analyzed through descriptive and inferential statistics. Major findings were; majority of BS students had markedly high level emotional intelligence and had excellent, very good and good levels of academic achievement. Female BS students had higher academic achievement than male BS students but emotional intelligence level was equal. There was significant moderately strong and positive relationship between academic achievement and emotional intelligence of BS students. For students having low level in different sub factors of the emotional intelligence it is recommended that university may design sports activities, seminars, and workshops to enhance not only their emotional stability but emotional intelligence as well.
\end{abstract}

Keywords: university students, academic achievement, emotional intelligence

\footnotetext{
Assistant Professor, Department of Education, University of Sargodha, drmamalik@gmail.com

** Assistant professor, Department of Education, University of Malakand, asghar9290100@yahoo.cm

${ }^{* *}$ M. Phil Scholar Department of Education, University of Sargodha

Bakhtawartariq21@gmail.com
} 


\section{Introduction}

It is the intelligence due to which human beings think rationally and respond as the situation demands (Moshahid,2017).Some studies have identified weak relationship between emotional intelligence (EI) and academic achievement (Shahid \& Malik, 2016). But few other researchers such as Chamundeswari (2013) and Sinha, Babli and Suman (2013) have found significant relationship between academic performance and emotional intelligence. Emotional intelligence is the ability of persons to make reasoning for their emotions and moreover the capacity to use their emotions and information about their emotions for assistance in reasoning (Mayer, Roberts \& Barsade, 2008).

As Elias and Arnold (2006) described EI as a collection of skills necessary for effective social collaboration and classroom achievement such as (a) empathy to be aware of and comprehend others feeling, (b)emotional recognition and regulation, (c) self-control to positively and effectively control emotions, (d) goal setting, (e) conflict resolution, (f) social responsibility while working in a social group and working with others, (g) ability to productively solve problems of any individual and social nature, (h) leadership skills needed for real involvement in group tasks such as communication, motivation, positivity, creativity etc.

Better emotional intelligence plays a key role to enhance learning skills (Nwadinigwe \& Azuka-Obieke, 2012). Brain is the place where emotions and learning take place. Knowledge is gained and skills are learnt. Our emotions are affected by thoughts. The relations of emotion and learning are bi-directional and complex process. Emotions are the transmission programs between sensory input and thinking. The constructive interpretation of the sensory input leads to act and motivate for achieving an objective. The destructive input results no learning (Triesch, (2015). Anxiety, anger and depression or other negative emotions can cause problems in learning process (Lawson, 2002). When a person responds to learning environment according to his/her emotions, it is called learning; such as response to instructional environment of classroom (Flood, 2003) answering to questions, participating in discussion etc.

Accomplishments of student's objectives are predicted by intelligence quotient (IQ) for upcoming events but emotional intelligence is used for anticipation of success since start of the $21^{\text {st }}$ century as compared to other cognitive intelligence. EI is the factor which is used by students to adjust successfully in varying environment (Hettich, 2000). 
In the contemporary world, education is getting broadened and there are intensive competitions among students to achieve excellent achievement. In university life students face various situations where they feel difficult to control their emotions. It is essential to manage stress and anxiety of students which ultimately affects their academic achievement. The basic components of emotional intelligence are 'confidence', 'self-control', 'relatedness' 'curiosity', 'ability to collaborate' and 'capacity to communicate'(Vasudevan, 2013). It has been established as predictor of future success instead of traditional methods e.g. IQ, standardized test scores and GPA (Lawrence \& Deepa 2013). Parents and teachers always focus on academic performance and intelligence and they take emotions as least important. There are many effects of emotions on students' performance ability. Though students can gain subject knowledge through their intelligence, but enhancement of students' learning ability is only possible through emotional intelligence which can make them efficient as well as high achievers (Rupande, 2015). It is concluded in many researches that persons managing their own feelings in well manner and they are able to deal effectively with their academic problems (Pandey, Gupta, Pandey, \&Giri, 2019; Tyagi, \& Gautam, 2017; Malik \& Shahid, 2016; Ebinagbome, \& Nizam, 2016; Hadiwijaya, \& Hutasoit, 2017). Low emotional intelligence increase levels of conflicts among young students (Chamundeswari, 2013). There is need to study the level of emotional intelligence and its relationship with academic achievement of university students.

\section{Review of Related Literature}

The historical origins of EI are not very ancient which can be traced to Edward Thorndike's, the writer who introduced the concept of "Social Intelligence" in the 20th century (1920). In his early studies, he described emotional Intelligence (EI) as evaluation and description of socially proficient behavior (Chapin, 1942; Doll, 1935; Thorndike, 1920).

The first instrument was designed by Doll, (1935), to measure young children's socially intelligent behavior. Two further subscales 'Picture Arrangement '\&'Comprehension' were included by Wechsler,(1939), in his famous test of cognitive intelligence developed for the measurement of different aspects of social intelligence. Soon after during 1940, Wechsler published his first test describing the influence of non- cognitive aspects of intelligent behavior. Later on during 1943, he 
himself discussed that the models of intelligence is not able to complete all the factors.

The researchers made extensive studies and after 1980 they were ultimately able to move forward and instead of focusing their attention about EI shifted to considerate the rationale of interpersonal \& intrapersonal behaviors and its role performed in effective adaptableness (Zirkel, 2000). While general intelligence is the capability of the individuals to act with determination (Wechsler, 1939). During 1983, Howard Gardner generated the term "Multiple Intelligence" and highlighted the importance of 'interpersonal' and 'intrapersonal' intelligences. Saarni (1999) described eight emotional capabilities that interconnected social skills and emotions. Researchers showed that emotional intelligence and social intelligence including interpersonal and intrapersonal capabilities can be merged to determine effective human behavior.

Modern theorists like Salovey and Mayer (1990) used the words of 'emotional intelligence' and originally analyzed emotional intelligence separate from social intelligence. Emotional intelligence involves inter related capabilities i.e. the ability to recognize correctly, apply, understand, and control emotions. According to Cherniss, \& Goleman, (2001) Emotional Intelligence' is more important than IQ and any other characteristics for success of a student and also suggest a person's recognition, knowledge, exercise, and ability to manage emotions and for success, in nearly every job, these emotional and social abilities are vital. Goleman (1995) said that the EI matters more in more complex jobs.

Right from the time of Thorndike (1920), many different complex ideas of emotional intelligence and social intelligence became visible by the creation of attractive combination of disagreement, uncertainty and prospect concerning the better way to define the construct. Bar On, (2006) described three major theoretical models of emotional intelligence in 'Encyclopedia of Applied Psychology' in order to clarify the role of EI in students success; (i) 'Bar-On's EmotionalSocial Intelligence (ESI) model' (Bar- On 2006), (ii) 'the competencies model focused on the workplace' (Goleman, 1998; 2001; Salovey \& Mayer 1990; Brackett \& Salovey, 2006)and EI Performance Model (Faltas, 2017).

\section{Emotional Intelligence Model by Daniel Goleman}

Goleman (1995) introduced the term 'Emotional Intelligence' in his book. He explained that these abilities have influence many areas of 
our lives. He further stated that there are five essential elements of EI i.e. Knowing one's emotions, recognizing emotions in others, handling relationships, and managing emotions, motivating emotions oneself. In a second book Goleman (1998) described an organizations based model of emotional intelligence; in it a theory of performance in organizations was explained. This model forecast the efficiency and outcome of persons in the place of work in an organization (Goleman, 1998). This model was composed of a number of abilities. These abilities are taken as characteristic of brilliant and successful employees (Goleman, 2001). The previous version of organizations based model contained twentyfive emotional competencies and five magnitudes of EI. At present, the model offers four (4) significant proportions, which further distribute more than twenty capabilities (Goleman, 2001): (1) 'Autonomous Self Evaluation', 'Self-Determination (2) 'sympathy', 'organizational consciousness' and' service hearing 'social awareness, and; (3) selfcontrol, self-control' in self-determination, self-control, and self-esteem; , 'Honesty', 'Success Drive', 'Transport' and 'Notification'; and finally, (4) Relationship Management, including others' development, leadership, impact, communication, authority, building bond, dispute management, teamwork and Include collaboration. It is further explained by Goleman (2001) that mostly the learned abilities or competencies needed in the organizational field based on any of these four dimensions e.g., the growth of scholarly competencies is based on self-awareness domain which helps in judging the precise self-assessment of the benefits and shortcomings of any alternative in decision making processes. Further he defined that emotional competence is an acquired ability that helps for exceptional performance in any task.

In order to comprehend the idea of academic proficiency described by Mayer, Salovey, \& Caruso, (2002) indicates innate capacity of managing particular emotional abilities. Goleman's suggestion was that emotionally competent person shows the level of control over capabilities or skills developed on the basis of their emotional intelligence level due to which he become more efficient in her/his work (Goleman, 2001).

\section{Emotional-social intelligence model of Bar-On}

Bar-On model is also called mixed up mental capabilities such as emotional self-awareness with other aptitudes e.g., personal independence, self-regards and mood (Mayer, Salovey, \& Caruso, 2002). Emotional intelligence or social intelligence is an example of interconnected social skills and emotional competencies that regulate 
how excellently one can comprehend and express oneself, understands others and communicates with them, and works for daily stresses (BarOn, 2006). An expression on perceptual aspect exemplifies a distance from the expected initiation of intelligence which put light on the significance of emotional issues (Bar-On, 2000, 2004, 2006). Bar-On's model describes the thoughts not only about social intelligence but also about emotional intelligence. These intelligences are shaped through complex depiction of mutually related traits of personality and emotions interacting with each other in the individual. There are five factors of emotional and social intelligence that are further subdivided in to fifteen sub-factors (Tripathy, 2018).

1) Intrapersonal Skills: 'communicates the feelings, ideas in the self, capability of being conscious and identify emotions, and it is divided into the five sub-factors, i.e. self-regard, emotional self-awareness, self-actualization, independence and assertiveness.

2) Interpersonal Skills: make reference to the capability of being conscious and accepting feelings of others' emotions. It is further sub-divided into three sub-factors, i.e., interpersonal relationship, social responsibility and empathy.

3) Adaptability: It is like the capacity of a person to accommodate his feelings according to the situations. There are three sub-factors in it i.e. flexibility, reality-testing and problem-solving.

4) Stress Management: It is the ability to manage anxiety and emotions. It also has three sub-factors i.e. stress, impulse control and tolerance.

5) General Mood: It represents the ability of managing feelings and emotions and it is to be optimistic. It also have sub-factors i.e. optimism and happiness (Bar-On, 2006).

\section{Measuring Emotional and Social Intelligence (ESI)}

In view of evaluating the factors and sub-factors described in his model, Bar-On first developed a viable tool to measure EI (Bar-On, 1997). Afterwards, he designed many instruments such as self-report measure for different age groups and questionnaires for external rate and interviews. This is very important to understand Emotional Quotient Inventory (EQ-i) which is a self-assessment measure of emotional and social intelligence. This EQ-I pertains 58 items and 15 sub-scales of the particular factors of emotional and social intelligence. These items use five point rating scale (Bar-On, 2006).

Emotions Quotient inventory (EQ-I) is an inventory with widespread range of social and emotional capabilities. Along with emotional intelligence level it also measure emotional and social profiles 
(Bar-on-2000). As a result Bar-onmodelis considered as a diverse emotional intelligence model, as it covered cognitive, emotional social, and personality dimensions (Mayor, Salovey, \& Carasso, 2002). It focuses on psychological features on the basis of its organization's EQ-I, its conceptual, analytical meaningful, overall classical construction (i.e. cognitive intelligence and personality) and unpaid input for daily life principles (Bar-on, 2004, \& 2006).

\section{Reliability of the Bar-On model}

EQ-I reliability was reviewed by many researchers in the last two decades. Contextual results show that the hypothetical and analytic model on the bar-on is reliable, consistent and stable specially, the reliability of EQ-i overall internally stable and centered on the standard sample was 0.97 (Bar-on, 2004). Internal stability was re-examined at 51,623 adults in North America, with a slight increase of mean $(\mathrm{M}=.025)$. EQ-i's overall retest reliability was 0.72 and 0.82 (Bar-on, 2004). Many researchers reported similar results about the EQ-i's reliability (Nwadiningwe, \& Azuka-Obieke, 2012).

After evaluating many emotional intelligence models, generally there are two parts of emotional intelligence. Firstly, it demands identification of personal emotions of individuals and then management of those to promote emotional capability. Secondly, it includes their potential to feel other person's emotion to create constructive social relations which are needed in the field of education. Teachers need to deal with their feelings and they must also manage their relationship with their peers, parents and students. They need to improve their emotional intelligence to succeed in their field (Vaziri, Azimi, \& Kashani, 2012).

Use of students' abilities in studies to remember facts and communication in oral form or in written form during examination or assessment is called academic achievement. There different factors counted for academic achievement such as attitude of students' towards studies or school, study habits, motivation self or gained through parents and teachers, intelligence, interest or aptitude in learning different subject, self-efficacy etc. On the other hand Udoh (2005) described that academic performance is based on psychological and sociological factors. Moreover Suleman, Q., Hussain, I., Ali Syed, M. I., Parveen, R. Lodhi, I. S., \& Mahmood, Z. (2019) has concluded that EI is also a factor affecting academic performance of students. 
Studies on Emotional Intelligence and Academic Achievement

Ranjbar, Khademi and Areshtanab (2017) conducted a metaanalysis of 23 articles about relationship of emotional intelligence and academic achievement among university students in Iran. They have identified weak relationship between emotional intelligence and academic achievement. Fallahzadeh (2011) conducted a study on academic achievement and emotional intelligence among 233 (70 males and 153 females) medical science students in Iran. He found significant difference in the academic achievement and emotional intelligence scores. He also concluded that EI improved students' mental health and they accomplish their task more successfully.

Khishtandar (2006) concluded that emotional intelligence is essential psychological concept, its full understanding is necessary with respect to student's academic achievement especially the students enrolled in the Universities or higher education institutions. University has different culture, environment and learning process as compared to colleges and schools. During university life students enhance their abilities and capabilities along with their academic achievement. In Pakistan many studies were conducted on the relationship between emotional intelligence and academic achievement such as Adnan, Chaudhry and Malik (2012) on students of management sciences; similarly Suleman, Hussain, Syed, Parveen, Lodhi, \& Mahmood, (2019) conducted study on science and technical students, Kayani, Kayani, \& Saleem (2015) conducted similar students on postgraduate level students of Public Sector Universities of Rawalpindi Pakistan; Malik, \& Shahid, (2016) conducted a similar study on business students but no study was available on undergraduate students. So, it is needed to study the levels of emotional intelligence of students to help them in achieving personal distinction in the subjects they are studying.

\section{Objective of the Study}

The study was opted to find out the relationship between emotional intelligence and academic achievement of undergraduate (BS) program students.

\section{Research Questions}

1. What is the emotional intelligence level of undergraduate (BS) students?

2. What is the gender wise difference in student's score of emotional intelligence? 
3. What is the difference between student's emotional intelligence score with respect to department /discipline?

4. What is the academic achievement level of undergraduate (BS) students?

5. What is the difference between student's academic achievement scores with respect to gender?

6. What is the relationship of emotional intelligence with academic achievement of undergraduate (BS) students?

\section{Methodology of the Study}

The study was quantitative and co relational research design was used to determine the relationship between emotional intelligence and academic achievement of university students enrolled in BS programs.

\section{Population and Sampling}

Due to financial constrain and shortage of time this study was delimited to all the undergraduate (BS)programs students studying in final semester in Fourteen (14) Departments of Seven (7) Faculties of main Campus University of Sargodha which were taken as the population of the study.

A representative sample was selected through multistage random sampling technique described as follows.

1. Using simple random sampling technique departments were selected from each of seven faculties. From large faculties; three to four (3 to 4) out of nine departments were randomly selected and from small faculties having maximum five or less departments; one to two departments ( 1 to 2 ) were randomly selected. Hence, overall 14 departments were selected randomly.

2. From each selected department 30 undergraduate (BS) students of final semester were selected randomly. In such a way 420 students were selected as sample of the study.

\section{Research Instrument}

A bilingual version of EQ-i (Short)(Bar-On (2003)was adapted by incorporating Urdu translation of each item for the convenience and better comprehension of the respondents and used to measure students Emotional Intelligence with the permission of author. It comprised of 51 items. It was validated through five experts opinions and pilot tested with one hundred final semester undergraduate (BS) students which were not 
included in the actual sample. The reliability coefficient Cronbach Alpha values was 0.86 .

\section{Data Collection}

Data was collected through self-approach, 420 copies of the questionnaire (Bar-On EQ-I short form was distributed, out of which 400 copies were received back. The response rate was $95 \%$.

\section{Data Analysis}

Quantitative data was analyzed by applying descriptive statistics; such as frequencies, percentage, mean, and standard deviations and inferential i.e. $t$-test through SPSS 22, one way ANOVA and Person correlation.

\section{Results}

Results of analysis are presented in the tables as follows.

Table 1

Undergraduate (BS) Students Emotional Intelligence level

\begin{tabular}{lrrr}
\hline Level & Range & Total & Percentage \\
\hline Markedly High & $130+$ & 399 & $99.8 \%$ \\
Very High & $120-129$ & 0 & $0 \%$ \\
High & $110-119$ & 1 & $0.3 \%$ \\
Average & $90-109$ & 0 & $0 \%$ \\
Low & $80-89$ & 0 & $0 \%$ \\
Very Low & $70-79$ & 0 & $0 \%$ \\
Markedly Low & Under 70 & 0 & $0 \%$ \\
& Total & 400 & $100 \%$ \\
\hline
\end{tabular}

Table 1 shows Students Emotional Intelligence level according to BarOn (2002) that majority of undergraduate (BS) students $(99.8 \%$ ) had markedly high level of emotional intelligence. There was only one male $(0.3 \%)$ having high level emotional intelligence. 
Table 2

Gender comparison of students' EI Score

\begin{tabular}{llllll}
\hline Gender & Mean & SD & $t$ & $d f$ & $p$-value \\
\hline Male & 233.6 & 34.41 & -.680 & 398 & .497 \\
Female & 235.8 & 31.58 & & & \\
\hline
\end{tabular}

Table 2 shows no gender wise statistically significant difference of emotional intelligence score existed among undergraduate(BS) students as indicated by $\mathrm{t}$-value $=-0.680$ with $\mathrm{df}=398$ and $\mathrm{p}$-value $=0.497>$ 0.05 .

Table 3

Department wise comparison of Emotional Intelligence

\begin{tabular}{|c|c|c|c|c|c|}
\hline & Sum of Squares & $d f$ & Mean Square & $F$ & $P$-value \\
\hline Between Groups & 16037.101 & 2 & 8018.550 & 7.743 & .001 \\
\hline Within Groups & 411138.649 & 397 & 1035.614 & & \\
\hline Total & 427175.750 & 399 & & & \\
\hline
\end{tabular}

Table 3 depicts that there existed significant difference in the mean scores of emotional intelligence of undergraduate (BS) students belonging to different departments of the university of Sargodha, as indicated by $F=7.743$ and $p$-value $=0.00<\alpha=0.05$ to find out the magnitude of the difference post hoc test Turkey's highest significant difference (HSD) was applied and only significant results are given in the following table 4

Table 4

Post hoc comparison of Students Emotional Intelligence with respect to departments

\begin{tabular}{lllll}
\hline $\begin{array}{l}\text { Department } \\
\text { (I) }\end{array}$ & $\begin{array}{l}\text { Department } \\
(\mathrm{J})\end{array}$ & $\begin{array}{l}\text { Mean difference } \\
(\mathrm{I}-\mathrm{J})\end{array}$ & Std. Error & P-value \\
\hline Sciences & Social sciences & $16.33479^{*}$ & 4.24597 & .000 \\
& Humanities & $-13.69875^{*}$ & 4.40304 & .006 \\
Humanities & Social sciences & $13.69875^{*}$ & 4.40304 & .006 \\
\hline
\end{tabular}

Table 4 indicates that emotional intelligence of BS students of sciences departments were better than BS students of social sciences departments as indicated by 16.33479 and $p$-value $=0.000<\alpha=0.05$, whereas emotional intelligence of BS students of social sciences departments were less than BS students of sciences and humanities departments as 
indicated by mean difference $-16.33479,-13.69875$ and $p$-value $=0.000$, $0.006<\alpha=0.05$.

BS students of humanities departments were better than BS students of social sciences departments as indicated by 13.69875and pvalue $=0.006<\alpha=0.05$

Table 5

BS Students' Academic Achievement level based on Gender

\begin{tabular}{lrrrrrc}
\hline Level & Male & Percentage & Female & Percentage & Total & Percentage \\
\hline $\begin{array}{l}\text { Unsatisfactory } \\
\text { (Below 2 CGPA) }\end{array}$ & 0 & $0 \%$ & 0 & $0 \%$ & 0 & $0 \%$ \\
$\begin{array}{l}\text { Satisfactory } \\
(2 \mathrm{CGPA})\end{array}$ & 1 & $0.62 \%$ & 0 & $0 \%$ & 1 & $.3 \%$ \\
$\begin{array}{l}\text { Fair } \\
(2.01-2.50 \mathrm{CGPA})\end{array}$ & 24 & $15 \%$ & 45 & $18.7 \%$ & 69 & $17.25 \%$ \\
$\begin{array}{l}\text { Good } \\
(2.51-3.00 \mathrm{CGPA})\end{array}$ & 50 & $31.2 \%$ & 56 & $24 \%$ & 106 & $26.5 \%$ \\
$\begin{array}{l}\text { Very Good } \\
(3.01-3.50 \text { CGPA) }\end{array}$ & 66 & $41.2 \%$ & 85 & $35.4 \%$ & 151 & $37.75 \%$ \\
$\begin{array}{l}\text { Excellent } \\
(3.51-4.00 \mathrm{CGPA})\end{array}$ & 19 & $11.8 \%$ & 54 & $22.5 \%$ & 73 & $18.2 \%$ \\
Total & 160 & $100 \%$ & 240 & $100 \%$ & 400 & $100 \%$ \\
\hline
\end{tabular}

In this Table 5 six levels of academic achievement; for unsatisfactory academic achievement level value (below 2CGPA) were taken. Satisfactory academic achievement level value (2CGPA). Academic achievement fair level values from (2.01-2.50CGPA) were taken. Good academic achievement level value (2.051-3.00CGPA). Very Good academic achievement level value (3.01-3.50CGPA) and excellent level of academic achievement value ranging from (3.51-4.00CGPA) were taken.

Overall $37.75 \%$ students had very good academic achievement level, 26.5\% students had good academic achievement level, $18.2 \%$ students had excellent academic achievement, $17.25 \%$ students had fair academic achievement level and only $0.3 \%$ students had satisfactory academic achievement level.

$37.75 \%$ undergraduate (BS) student's (151), including 41.2\% male students (66) and $35.4 \%$ female students (85) had very good academic achievement. While $26.5 \%$ undergraduate (BS) students (106), including 31.2\% male students (50) and 24\% female students (56) had good academic achievement. The remaining $18.2 \%$ undergraduate (BS) students (73), including $11.8 \%$ male students (19) and $22.5 \%$ female students (54) had excellent academic achievement. $17.25 \%$ 
undergraduate(BS) students including 15\% male students (24) and $18.7 \%$ female students (45) had fair academic achievement and only $0.62 \%$ male students (1) and $0 \%$ female students (0) had satisfactory academic achievement. Majority of students 55.7\% (224) had very good/excellent academic achievement.

Table 6

Comparison of academic achievement of undergraduate (BS) students with respect to gender

\begin{tabular}{lcccccclc}
\hline Gender & $\mathrm{N}$ & Mean & SD & $t$ & $d f$ & $P$-value & $\begin{array}{l}\text { Effect } \\
\text { Cohen's d }\end{array}$ & size \\
\hline Male & 160 & 3.05 & .367 & -3.203 & 398 & .001 & 0.33 \\
Female & 240 & 3.18 & .417 & & & & & \\
\hline
\end{tabular}

Table 6indicates existence of statistically significant difference in academic achievement of male and female students as indicated by $\mathrm{t}=$ 3.203 , $\mathrm{df}=398$ and $\mathrm{p}=0.001<\alpha=0.05$. The higher mean score $=3.18$ and $\mathrm{SD}=.417$ shows that female undergraduate (BS) students had higher level academic achievement than male students (mean score $=3.05 \&$ $\mathrm{SD}=.367$ ). But according to value of effect size 0.33 this difference is small.

Table 7

Correlation between undergraduate (BS) students' Academic Achievement and Emotional intelligence

\begin{tabular}{lcc}
\hline & Pearson correlation $(\mathrm{r})$ & $p$-value \\
\hline Academic Achievement & & \\
Emotional Intelligence & .494 & .000 \\
\hline
\end{tabular}

$(\mathrm{N}=400)$

Table 7 shows that there was significant, moderate and positive relationship between undergraduate (BS) students' academic achievement $(\mathrm{M}=3.12, \mathrm{SD}=0.40)$ and emotional intelligence $(\mathrm{M}=234.97$, $\mathrm{SD}=32.72)$ as indicated by Pearson(r)-value $=.494$ and $\mathrm{p}$-value $=.000<$ $\alpha=0.05$. 
Table 8

Correlation between undergraduate (BS) students' academic achievement and EI sub factors

\begin{tabular}{lllll}
\hline & Mean & SD & $(\mathrm{r})$ & $p$-value \\
\hline Academic Achievement & 3.12 & 0.40 & & \\
Intrapersonal Skills & 80.32 & 11.68 & .470 & .000 \\
Academic Achievement & 3.12 & .403 & & \\
Interpersonal Skills & 41.21 & 6.08 & .429 & .000 \\
Academic Achievement & 3.12 & .403 & & \\
Adaptability Skills & 47.59 & 7.63 & .471 & .000 \\
Academic Achievement & 3.12 & .403 & & \\
Stress Management Skills & 31.95 & 5.45 & .416 & .000 \\
Academic Achievement & 3.12 & .403 & & \\
General Mood Skills & 33.88 & 5.49 & .405 & .000 \\
\hline
\end{tabular}

Table 8 shows that there was significant, moderately strong and positive relationship between, BS students' academic achievement and EI sub factors i.e. intrapersonal skills, adaptability skills, stress management skills and general mood skills as indicated by Pearsons-values $=.470$, $.429, .471, .416, .405$ respectively and $p$-value $=.000<\alpha=0.05$.

\section{Findings and Discussion}

1. Emotional intelligence (EI) of BS students of university had markedly high level.

2. Male and female undergraduate (BS) students' emotional intelligence score was not different. According to earlier researchesof Bar-On, $(2000,2004,2006)$ there were small gender based differences in few of the factors measured by the EQ-I. More speciffically, Bar-on model indicates females appear to have better interpersonal skills, more awake about their emotions, can better manage the emotions, show more sympathy and more social responsiblity than males. While males showssuperior self regards, better flexiblity, handle well with stressed situations, have good problem solving and good optimism than females.Yong (2003) also concluded that male and female had equivalent emotional intelligence scores. The finding of this study is not in line with the research findings of Mansoori's (2001) that there was gender difference in the score of emotional intelligence scores.

3. Emotional intelligence of BS students of sciences departments was better than BS students of social sciences departments, whereas emotional intelligence of BS students of social sciences departments 
were less than sciences and humanities departments of BS student's. BS students of humanities departments were better than BS students of social sciences departments.

4. Majority of the BS students has excellent very good and good levels of academic achievement. Female BS students had higher academic achievement than male BS students.

5. Results of this study indicates that emotional intelligence and its factors (intrapersonal, interpersonal, adapability, general mood \&stress management) had a significant, moderatly strong and positive relationship with academic achievement. These findings are consist with the results of the research conducted to explore the effect of emotional intelligence on academic sucees (Bar-on, 2004; Chapin, 2015). They concluded that factors of emotional intelligence which are managing and regulating one's feeling, general mood skills,intrapersonal, interpersonal and problem solving, have significant relationship with academic success for example, a students who manage his emotionswould be able to handle theanxiety and stress during his presentation, test and examination. Futhermore ability of using interpersonal skill may help students to get academic help from fellows,resources persons and teachers, moreover the ability of using intrpersonal skill wouldhelp students in struggle of achieving own goals and realize his/her potential. Ability to genernal mood skill may assist students hope for best and motivated to achieve academic success.

\section{Recommendations}

Recommendations made on the basis of findings and conclusions drawn from the data analysis of the study are as follows:

- Students of social sciences were behind the students of humanities and sciences. So, it is recommended that university teachers of social sciences departments may design activities to increase communication skills and emotional competence skills for better self-awareness skill of the students.

- Female students having low emotional intelligence as compared to male students, it is recommended that university teachers may design sport activities, seminars, conferences and workshops for students to increase emotional stability which lead them to increasing emotional intelligence. 


\section{References}

Adnan, A., Chaudhry, A. A., \& Malik, M. I. (2012). Emotional Intelligence and Students' Academic Performance: A Study Conducted in Pakistan and Afghanistan. Science Series Data Report, Vol 4, No. 3. Retrieved from https://www.researchgate.net/publication/256039427

Bar-On, R. (1997). The Emotional Quotient Inventory (EQ-i): A test of emotional intelligence. Toronto, Canada: Multi-Health Systems, Inc.

Bar-On, R. (2000). Emotional and social intelligence: insights from the emotional quotient inventory. In Bar-On, R. \& Parker, J. D.A. (eds.): Handbook of emotional intelligence (pp. 363-388). San Francisco: Jossey-Bass. Retrieved from https://www.amazon.com/Handbook-EmotionalIntelligence...at/dp/0470907436

Bar-On, R. (2004). The Bar-On Emotional Quotient Inventory (EQ-i): rationale, description and summary of psychometric properties. In G. Geher (ed.): Measuring emotional intelligence: common ground and controversy (pp. 111-142). Hauppauge, NY: Nova Science Publishers. Retrieved faculty.newpaltz.edu/glenngeher/.../Geher_and_Renstrom_2004a in_G_Geher_ed.pd

Bar-On, R. (2006). The Bar-On model of emotional-social intelligence (ESI). Psicothema, 18, 13-25. Retrieved from https://www.eiconsortium.org

Bar-On, R., \& Handley, R. (2003). The Bar-On EQ-360: Technical manual. Toronto, Canada: Multi-Health Systems. Retrieved from http://eqi.mhs.com

Brackett, M. \& Salovey, P. (2006).Measuring emotional intelligence with the Mayer Salovey - Caruso Emotional Intelligence Test (MSCEIT). Psicothema, 18, 34-41. Retrieved from www.psicothema.com/pdf/3273.pdf 
Chamundeswari, S. D. (2013). Emotional Intelligence and Academic Achievement among Students at the Higher Secondary Level. International Journal of Academic Research in Economics and Management Sciences, 2(4) 178-187. Retried from http://hrmars.com/index.php/journals/papers/IJAREMS/v2$\mathrm{i} 4 / 126$

Chapin, F. S. (1942). Preliminary standardization of a social impact scale. American Sociological Review, 7, 214-225. Retried from http://journals.sagepub.com/doi/abs/10.1177/0734282996014003 05

Chapin, K. (2015). The Effect of Emotional Intelligence on Student Success. Journal of Adult Education, v44, n-1, 25-31. Retrieved from https://files.eric.ed.gov/fulltext/EJ1072926.pdf

Cherniss, C., \& Goleman, D. (2001).The Emotionally Intelligent Workplace. Jossey-Bass Business \& Management Series. Retrieved from https://www.ftms.edu.my/images/Document/MOD00946

Doll, E. A. (1935). A generic scale of social maturity. American Journal of Orthopsychiatry, 5, 180-188. Retried from http://onlinelibrary.wiley.com/doi/10.1111/j.19390025.1935.tb06339.x/abstract

Ebinagbome, M. E., \& Nizam, I. (2016). The Impact of Emotional Intelligence on Student's Academic Performance: A Study on Malaysian Tertiary Institution. International Journal of Accounting \& Business Management, Vol. 4. No.1. DOI: 10.24924/ijabm/2016.04/v4.iss1/10.18

Elias, M. J., \& Arnold, J. (Eds.). (2006). The educator's guide to emotional intelligence and academic achievement. Thousand Oaks, CA: Corwin Press. Retired from: https://www.amazon.com/Educator/dp/1412914817

Fallahzadeh, H. (2011). The Relationship between Emotional Intelligence and Academic Achievement in medical science students in Iran. Procedia - Social and Behavioral Sciences, 30, 1461-1466. Retried from https://core.ac.uk/download/pdf/82390077.pdf 
Faltas, I. (2017). Three models of emotional intelligence. Retrieved from https://www.researchgate.net/publication/314213508 Three_Mo dels_of_Emotional_Intelligence/download

Flood, J. (2003). Successful online learning: The five P's. Training Journal, 30-32. Retried from:

http://www.irrodl.org/index.php/irrodl/article/view/385/1036

Goleman, D. (1995). Emotional intelligence. New York: Bantam Books.

Goleman, D. (1998). Working with emotional intelligence. New York: Bantam Books. Retrieved from citeseerx.ist.psu.edu/viewdoc/download?doi=10.1.1.201.6135\&r ep $=$ rep $1 \ldots . . p d f$

Goleman, D. (2001). Emotional intelligence: perspectives on a theory of performance. In C. Cherniss \& D. Goleman (eds.): The emotionally intelligent workplace. San Francisco: Jossey-Bass. Retrieved from www.josseybass.com

Hadiwijaya, H., \& Hutasoit, G. (2017).Effect of Emotional Intelligence on Student Learning Achievement. GUIDENA, Volume 7, Number 1, Page 29-39. DOI: 10.24127/gdn.v7i1.663

Hettich, P. (2000). Transition processes from college to career. Eric document no.:ED447368. Retried from: https://www.academia.edu/2590707/emotional_intelligence and _academic_achievement_of high_school_students_in_kanyaku mari district

Kayani, S., Kayani, S., \& Saleem, S. (2015).Relationship between Emotional Intelligence and Academic Achievement of Postgraduate Students in Pakistan. International journal of innovation and scientific research. Vol. 15, pp-202-206.

Khishtandar, P. (2006). A study of the relationship between emotional intelligence and social support with life satisfaction among high school students in the city of Boein. Unpublished Master's thesis, Faculty of Education and Psychology, Shahid Beheshti University. 
Lawrence, A., Deepa, T. (2013).Emotional intelligence and academic achievement of high school students in kanyakumari district. International Journal of Physical and Social Sciences, 3(2). Retried from: www.indianjournals.com/Mobile/JournalDetails.aspx?target=jou rnal\&ccode $=$ ijpss

Lawson , C. (2002). The connections between emotions and learning. Retried from http://www.cdl.org/articles/the-connectionsbetween-emotions-and-learning/

Malik, S. Z., \& Shahid, S. (2016). Effect of Emotional Intelligence on Academic Performance among Business Students in Pakistan. Bulletin of Education and Research, Vol. 38, No. 1 pp. 197-208. Retrieved from http://pu.edu.pk/images/journal/ier/PDFFILES/13_Sania\%20\&\%20Sehrish_v38_1_2016.pdf

Mansoori, B. (2001). Mannerism of Emotional Intelligence cyber or Sharing among M.A. students at the University of Tehran. Unpublished M.A. Thesis, University of Allameh Tabatabaee.

Mayer, J. D., Salovey, P., \& Caruso, D. R. (2002).Mayer-SaloveyCaruso Emotional Intelligence Test (MSCEIT). Toronto, Canada: Multi-Health Systems, Inc. Retried from http//doi/10.1177/15345084070330010601

Mayer, J.D., Roberts, R.D., \& Barsade, S.G. (2008). Human abilities: Emotional intelligence. The Annual Review of Psychology, 59, 507-536. http://www.annualreviews.org/doi/abs/10.1146/annurev.psych.5 9.103006.093646? journalCode $=$ psych \&

Moshahid, M. (2017). A Comparative Study of Emotional Intelligence among management and Engineering Students. International Journal of Academic Research and Development. Volume 2, Issue $\quad 4 . \quad 716-720 . \quad$ Retrieved from www.academicsjournal.com/archives/2017/vol2/issue4

Nwadiningwe, I. P., \& Azuka-Obieke, U. (2012).The Impact of Emotional Intelligence on Academic achievement of Senior School Students in Lagos, Nigeria. Journal of Emerging Trends in Educational Research and Policy Studies (JETERAPS) 3(4):395-40. Retrieved from jeteraps.scholarlinkresearch.com/ 
Pandey, P. K., Gupta, N., Pandey, P. K., \& Giri, P. (2019).The Impression of Emotional Intelligence on University Students' Academic Performance. International Journal of Recent Technology and Engineering (IJRTE), Volume-8 Issue-3. Retrieved from https://www.ijrte.org/wpcontent/uploads/papers/v8i3/C4583098319.pdf

Ranjbar, H., Khademi, H. S., \& Areshtanab, N. H. (2017). The Relation between Academic Achievement and Emotional Intelligence in Iranian Students: A Meta-Analysis, 34(1).Retried from https://www.degruyter.com/downloadpdf/j/afmnai.2017.34.issue -1/afmnai-2017-0008/afmnai-2017-0008.pdf

Rupande, G. (2015). The Impact of Emotional Intelligence on Student Learning. International Journal of Managerial Studies and Research (IJMSR) Volume 3, Issue 9, PP 133-136. Retrieved from https://www.arcjournals.org/pdfs/ijmsr/v3-i9/12.pdf

Salovey, P., \& Mayer, J. D. (1990). Emotional intelligence. Imagination, Cognition, and Personality, 9, 185-211. Retried from: https://www.coursehero.com/registerForm.php?reg_only=1\&get doc $=22409151$

Shahid, S., \& Malik, S. Z. (2016).Effect of Emotional Intelligence on academic performance among Business Students in Pakistan. Bulletin of Education and Research, Volume 38, No.1 pp 97-208. Retried from pu.edu.pk/home/journal/32/Online-Contents.html

Sinha, R., Babli, R., \& Sumon, S. (2013). Emotional Intelligence and Academic Achievement Motivation among Adolescents' Relationship Study. Journal of Arts, Science \& Commerce.4(2) Retried from http://www.researchersworld.com/vol4/issue2/Paper_18.pdf

Suleman, Q., Hussain, I., Syed, A. M. I., Parveen, R. Lodhi, I. S., \& Mahmood, Z. (2019). Association between emotional intelligence and academic success among undergraduates: A cross-sectional study in KUST, Pakistan. PLoS One, 14(7)doi: 10.1371/journal.pone.0219468

Thorndike, E. L. (1920) Intelligence and its uses. Harper's Magazine, 140, 227-235. Retried from https://www.unz.org/Pub/Harpers1920jan-00227 
Triesch, J. (2015). Imitation learning based on an intrinsic motivation mechanism for efficient coding. Frontiers of Psychology, 4: 800. doi: $10.3389 /$ fpsyg.2013.00800

Tripathy, M. (2018).A Study of Self-Confidence and Inferiority-Insecurity Feeling as Related to Academic Achievement. LAMBERT Academic Publishing. Retrieved from https://www.researchgate.net/ publication/335433637

Tyagi, G., \& Gautam, A. (2017). An Impact of Emotional Intelligence on the Academic Achievement of the student: A case study on students of Career Point University. International Journal of Advanced Scientific Research and Management, Vol. 2 Issue 7. Retrieved from http:/ijasrm.com/wpcontent/uploads/2017/07/ijasrm_V2S7_298_88_93.pdf

Udoh, A. O. (2012). Learning Environment as Correlates of Chemistry Students' Achievement in Secondary Schools in Akwa Ibom State of Nigeria. International Multidisciplinary Journal, Ethiopia, (6)26. 208-217. DOI: 10.4314/afrrev.v6i3.15

Vasudevan, H. (2013).The Influence of Emotional Intelligence and Creativity on Employee's Work Commitment and Performance. International Journal of Management \& Business Research, vol.3 (3). Retrieved from http://ijmbr.srbiau.ac.ir/article_2002_457b62c853f17596678494 7fa67406f0.pdf

Vaziri, S., Azimi, L.A., \& Kashani, L.F. (2012).Relationship between Emotional Intelligence and Educational Achievement. Procedia - Social and Behavioral Sciences, 69, 1270-1275. Retried from: https://ac.els-cdn.com/S1877042812055218/1-s2.0-

S1877042812055218-main.pdf?_tid=a762e536-e41b-11e7-af8f00000aab0f27\&acdnat $=1513619488$ ff306ab4170f5f9c489e462 $6396 \mathrm{a} 8813$ 
Wechsler, D. (1943). Non-intellective factors in general intelligence. Psychological Bulletin, 38, 444-445. Retried from: https://www.deepdyve.com/lp/psycarticles-reg/non-intellectivefactors-in-general-intelligence-8ZKzUloT09

Yong, L. (2003). The Yong EQ Inventory norms and technical manual. Retried from http://pi.leonard.com.my/pdf/Yong\%20EQ\%20Inventory\%20N orms\%20Technical\%20Manual.pdf

Zirkel, S. (2000). Social intelligence: The development and maintenance of purposive behavior. In Bar-On, R. \& Parker, J. D. A. (Eds.). Handbook of emotional intelligence. San Francisco: Jossey-Bass. Retried from https://www.amazon.com/Handbook-EmotionalIntelligence...at/dp/0470907436

\section{Citation of this Article:}

Ahmad, M., Ali, A., \& Tariq, B. (2019). Emotional intelligence and academic achievement of university students Pakistan Journal of Education, 36(3), 71-92.

DOI: $10.30971 /$ pje.v36i3.687.g197

To link this article: http://dx.doi.org/10.30971/pje.v36i3.687 